University of Louisville

ThinkIR: The University of Louisville's Institutional Repository

Electronic Theses and Dissertations

$1-1929$

\title{
The Mississippi question and the problem of statehood in Kentucky.
}

Harold J. Stipe

University of Louisville

Follow this and additional works at: https://ir.library.louisville.edu/etd

Part of the United States History Commons

\section{Recommended Citation}

Stipe, Harold J., "The Mississippi question and the problem of statehood in Kentucky." (1929). Electronic Theses and Dissertations. Paper 1387.

https://doi.org/10.18297/etd/1387

This Master's Thesis is brought to you for free and open access by ThinkIR: The University of Louisville's Institutional Repository. It has been accepted for inclusion in Electronic Theses and Dissertations by an authorized administrator of ThinkIR: The University of Louisville's Institutional Repository. This title appears here courtesy of the author, who has retained all other copyrights. For more information, please contact thinkir@louisville.edu. 


\section{UNIVERSITY OF LOUISVILLE}

The Mississippi Question and the Problem

of

Statehood in Kentucky

A Dissertation

Submitted to the Faculty

of the Graduate School of the College of Liberal Arts

in Partial Fulfillment of the

Requirements for the Degree

of Master of Arts

Department of History

By

Harold J. Stipe

1929 


\section{CONTENTS}

Page

I. The Growth of the Western Region ............. I

II. Kentucky and the Mississippi Question .......... 6

III. The Movement for Statehood in Kentucky .......... 20

IV. Kentuckians and Spaniards,

A Study in Uncertainties ..... 33

V. Statehood and Navigation Concluded ............ 57

VI. Bibliography $\ldots \ldots \ldots \ldots \ldots \ldots \ldots \ldots \ldots \ldots \ldots \ldots \ldots \ldots \ldots$ 
The Growth of the Western Region 
The history of new state movements in America is always an absorbing study; the character of the settlers and the compelling factors that motivate them are revealed with startilng clarity as the reader turns the pages back into the annals of the period. The history of America has been, in a large degree, says Frederick J. Turner, "the history of the colonization of the Great West. The existence of an area of free land, its continuous recession, and the advance of American settlement westward, explain American development."

In no state was the influence of the frontier advance upon political development shown more clearly than in Kentucky, the first settlement on the "western waters." It is a significant feature of this statehood struggle that it did not concern itself with purely local considerations but found its greatest impetus in a problem of national importance, the free navigation of the Mississippi. It is the purpose here to consider the interrelation of these two questions and Kentucky's role in their solution.

The migrations to the district were made despite the great distance from the older settlements, despite the menace from the Indians, and in constant disregard of the fact that Virginia could give neither adequate protection nor aid to those who dared to take up the life of the pioneer. It is not the purpose here to follow the story of the development of the settlement, but it is necessary to attempt to discover, if possible, the nature and the number of those who were so vigorously to influence the history of the western district. 
John Filson, who was to become the first of the recorders of the history of Kentucky, said: "We may conclude that Kentucky contains, at present (1784), upwards of 30,000 souls, so amazingly rapid has been the settlement in a few years. Numbers are arriving daily, and multitudes expected this Fall, which gives a well-grounded expectation that the country will be exceedingly populous in a short time. The inhabitants, at present, have not extraordinary good houses, as usual in a newly settled country."l

The close of the Revolution found a considerable part of the district surveyed and rapidly being taken up by grants. Real estate was being bought and sold, towns were laid out and began to assume respectable size. There was every evidence of permanency and healthy development, though the communities had, in no phase, lost their pioneer nature. 2 Filson's estimate of 30,000 inhabitants is greater than the number attributed to the district by more recent historlans, but of more importance than numbers, in any given year, was the fact of rapid and permanent growth. 3

It is necessary to consider, also, that the district did not offer sufficient lure to retain all who came into its borders. "Perhaps from ten to twenty thousand people a year,"

1. Reprinted in Mississippi Valley Historical Proceedings, Vol. VI, p. 112, from Filson, Discovery, Settlement and Present state of Kentucke, pp. 28 and 29. (A copy of this book is in the Wisconsin State Historical Society Library.)

2. For an interesting account by a contemporary writer see Gilbert Imlay, A Topographical Description of the Western Territory of North America, 1793, p. 45, ff.

3. Justin Winsor, in his Westward Movement, Boston, 1897, p. 178 , places the probable number of people in the district in 1783 at 12,000. The first Federal census, 1790, accorded to Kentucky 73677 persons. 
says Roosevelt, "came into Kentucky during the close of the Revolution; but the net gain to the population was much less, because there was always a smaller, but almost equally steady, counterflow of men who, having falled as pioneers, were struggling wearily back to their deserted eastern homes. "4

The student of early Kentucky history is constantly impressed with the qualities of leadership exhibited by many of those who were coming to make this region their homes. It is a common tendency to idealize the pioneer and to impute to him the sterling attributes of courage, honesty and sincerity without regard to the fact that the same term may apply to the ignorant and slothful individual who had drifted away from an older community. Such men were not lacking in Kentucky but their presence was more than offset by a vigorous, independent element, fully capable of assuming leadership in political and economic affairs. It is not surprising to find, then, that when differences of interests between East and West arose, there was in Kentucky a group that could champion ably and earnestly the interests of their adopted section.

With the growth of population, mills began to put in their appearance. Their products were to require markets if expansion was to continue. From the settled and semi-settled areas about the towns, beef, apples, salt and hemp promised profit to the man who could solve the difficult problem of sale for them. Aggressive action and decisive steps would be necessary if the economic future of the district was not to be thwarted and Kentucky to remain an isolated, backward community until such time as she would have a population sufficient to absorb her

4. Roosevelt, Winning of the West, Vol. III, pp. 15 and 16. 
products. In no such pronounced limitations upon its development could a pioneer community be expected to acquiesce, and Kentucky was no exception to the rule.

From the political standpoint alone, Kentucky was experlencing no serious disadvantages. There was no history of arbitrary rule by Virginia -- the district was simply administered as a county. But as the economic disability attendant upon the closed navigation of the Mississippi became more marked, political considerations began to loom large in the discussions in the state. Administration by a government removed by several hundreds of miles and under the direction of men who were not in touch with local matters caused the Kentuckians to feel that their economic salvation lay in statehood. In its simplest analysis, then, the history of Kentucky from 1783 to 1789 is the history of a section profoundly influenced by a movement for statehood which had as its chief object the securing of the free navigation of the Mississippi. 
Kentucky and the Mississippi Question 
The question of the control of the Mississippi River and Valley was agitated long before there was a population in that region sufficient to account for the interest shown. The foreign offices, with an ever watchful eye upon the possibility of colonial expansion, saw the potential value of the section. Madrid had watched with uneasiness the decline of French power in America; their common rival, England, was developing with an all too irresistible force her place in the New World. To Spain the all important problem seemed to be that of maintaining her hold upon the Gulf, both with respect to the colonies that surrounded it and the commerce that it carried.5 England's contraband trade with these colonies was increasing in an alarming fashion; aggressiveness with respect to trade might well be followed by aggressiveness with respect to colonies.

These conditions weighed heavily in inducing Spain to join France in her last struggle with England in America. Spanish apprehensions had more definite grounds in the preliminary treaty of 1762 between England and France. 6 France had agreed to cede to Great Britain the left bank of the Mississippi as far as the River Iberville and the lakes Maurespas and Pontchartrain. ${ }^{7}$ This clause would establish the Mississippi

5. See the statement of Floridablanca, Spanish Minister of State, to Jay, the American Commissioner to Spain (Wharton, Diplomatic Correspondence of the Revolution, Vol. IV, pp. 145 and 146 ).

6. Spain seemed to acknowledge the possibility of the defeat of the allies in the war with England. See Cantillo Tratados, convenios y declaraciones de paz y de commercio, (Translated by W. R. Shepherd in his "Cession of Louisiana to Spain," Political Science Quarterly, Vol. XIX, p. 440.)

7. William MacDonald, Documentary Source Book of American History, New York, 1916. 
as the boundary between Louislana and Canada and would give to Great Britain easy access to the sea. The possibility of such an outlet for Great Britain upon the Gulf of Mexico immediately awakened protest from Spain. 8

But news had come that Havana had fallen to the British and her commissioners were in a position to demand more severe terms. Spain must cede Porto Rico or all the Floridas if she wished to regain Havana. England must also have freedom of ascent as well as descent of the river " . . . it being distinctly understood that the navigation of the Mississippi River is to be equally free to the subjects of Great Britain and France, in its whole breadth and extent, from its source to the sea, and particularly that part between the said island of New Orleans and the right bank of the river, as well as the entrance and departure by its mouth." 9

Then, suddenly, France made a most surprising move. To make it possible for Spain to retain Florida, France offered Louisiana to England as a substitute. We are perhaps well within reason in conjecturing that France felt that she was giving up a burdensome province. But England was unwilling to accept the substitution. So with all the formality common to such occasions Louls XV wrote a personal letter to Charles III offering Loulsiana to Spain. The terms of the cession were soon drawn up. The preliminary convention of November 3, 1762, said: "The most Christian King, being firmly resolved to strengthen and perpetuate the bonds of tender amity which

8. Simancas Estado, Lega jo 4551, Wall, Minister of State to Grimald1, Ambassador to England, August 2, 1762. Translated by Shepherd, Political Science Quarterly Vol. XIX, p. 440. 9. Benjamin F. French, Historical Documents of Louisiana, New York, 1846, Vol. V, p. 240. 
unite him to his cousin, the Catholic King.. cedes in entire possession, purely and singly, without exception, to his Cathollc Majesty and his successors, in perpetuity all of the country known under the name of Loulsiana, as well as New Orleans and the island in which the place stands." 10

For Spain the possession of Louisiana might easily be a cause for trouble. There was the problem of the French inhab1tants and there was a possibility of trouble with England over 1t. On the other hand it was not a gift to be lightly rejected. The Mississippi could serve as a demarcation line for the Spanish territories; it might be the means of checking English advance into other western areas. Nor was it necessary to reckon the province of Louisiana as an economic Ilability; New Orleans alone could be compensation for administrative losses elsewhere.

To the district and state of Kentucky that was to be, the cession was of untold consequence. Had France retained it the probability is that it would have become a British possession in the period 1789-1815. Shepherd, in his excellent study of the cession, previously referred to, says that all conditions, geographical, economic, political and social, pointed to the formation of two confederacies, one along the Atlantic seaboard and one along the Mississipp1. With England intrenched beyond the Mississippi, the history of the settlements on the "western waters" might have taken a very different course.

The treaty between England and France was finally concluded on February 10, 1763. "It is agreed that, for the future, the confines between the territory of his Britannic

10. ibid., Vol. V, pp. 235 and 236. 
Majesty, and those of his most Christian majesty, in that part of the world, shall be fixed irrevocably by a line drawn along the middle of the river Mississipp1, from its source to the river Iberville, and from thence by a line drawn along the middle of this river, and the lakes Maurespas and Pontchartrain, to the sea; and for this purpose, the most Christian king cedes in full right, and guarantees to his Britannic majesty, the river and port of the Mobile, and everything which he now possesses, or ought to possess, on the left side of the river Mississippi, except the town of New Orleans, and the island on which it is situated, which shall remain to France; provided, that the navigation of the river Mississippi shall be equally free, as well to the subjects of Great Britain as to those of France, in its whole breadth and length, from its source to the sea, and expressly that part which is between the said island of New Orleans and the right bank of that river, as well as the passage both in and out of its mouth. It is further stipulated that the vessels belonging to the subjects of either nation shall not be stopped, visited or subjected to the payment of any dues whatsoever."ll spain, through her recent acquisition of the Loulsiana country, would have this privilege of navigation granted to France. Conversely, Great Britain's right to the navigation would be unimpaired by the transfer of Louisiana. These facts are important in the light of later changes in the territorial status of the two countries. During the American Revolution, Spain's diplomacy seems largely to have been controlled by a desire to protect her Louislana

11. Treaty of Paris, February 10, 1763, Art. VII (MacDonald, Documentary Source Book of American History). 
possessions. ${ }^{2}$ To insure her control over that region, a rigid domination of the Mississippi was deemed necessary. America was particularly anxious to secure Spanish aid during the war and Congress, on December 30,1776 , passed a resolution: "That if his Catholic majesty will join with the United States in a war against Great Britain, they will assist in reducing to the possession of Spain the town and harbor of Pensacola, provided the inhabitants of the United States shall have the free navigation of the Mississippi and the use of the harbor of Pensacola."13 The alliance between France and Spain was the occaston for persistent activity by Vergennes to secure cooperation from Spain. But Floridablanca, who had recently become the chief Spanish Minister of State, as persistently avoided the alliance. 14

Until her declaration of war against Great Britain in 1779, Spain had not concerned herself with the Mississippi Question. Apparently she admitted the English right to the navigation, but had she not, the undeveloped nature of the western country would have precluded controversy. But war with England meant the possibility of regaining Florida which would tend to reestablish Spain in her old preeminent place in the Caribbean. Likewise, the success of the United States would mean a more rapid advance into the West. Once more the Mississippi assumed a place of importance in diplomatic considerations.

12. Temple Bodley, History of Kentucky, 4 Vols., Louisville, 1928 , Vol. I, p. 215 f.

13. Diplomatic Correspondence of the Revolution, Blair Edition, Washington, 1837, Vol. II, p. 304.

14. For an account of the diplomatic manoeuvering of the three countries, France, Spain and the United States, see Justin Winsor, The Westward Movement, p. $160 \mathrm{f}$. 
The official Spanish observer, Juan de Mivalles, wrote to his home office as follows: "Having arranged to confer in my house and in that of the French minister with the new President of Congress (John Jay) and varlous members of 1t, I have explored (and the said plenipotentiary conspired to the same end) the idea which they hold as to the territory which the Americans have taken from the English in the interior of the province of Loulsiana, Illinois, etc. ... That the right which they have acquired from the English by conquest would give them the facility of exporting their produce by the Mississippi River which flows into the Gulf of Mexico."15

America was promised no help from France in obtaining any of her claims to the western country. Gerard, in a letter to Congress, dated May 22, 1779, said: "The success of the war being alone able to fix the fate of empires, it has been found impossible, on concluding the treaty of alliance, to determine the possessions that the United States may obtain on making peace; consequently the engagement of France can only be conditional and eventual on this subject. . . She is not now held to any particular engagement in relation to these possessions, whether real or pretended." He then said that "the claims to western lands were founded only upon far-fetched inductions subject to discussion and contradiction." 16

Though discouraged by France and receiving no hint of support by Spain, Congress went ahead in its plans for establishing a control over the western territory. The committee

15. Yela, Espana anta la independencia de los Etados Unidos, Vol. I, p. 387. (Reprinted in Samuel Flagg Bemis, Pinckney's Treaty, Baltimore, 1926, p. 15.

16. Wharton, Diplomatic Correspondence of the Revolution, Vol. III, p. 174 . 
appointed for the purpose presented its report upon the western boundaries to be asked for as "Southerly as the boundary settled between Georgia and East and West Florida; and westerly by the River Mississippi.17 A later report was more exact: "The middle of the River Mississippi from its source to that part of the said river which lies in latitude 31 degrees north from the equator, then by a line drawn due east to the River Apalachicola or Catahouche, thence to the junction thereof with the flint river, then in a strait line to the head of st. Mary's River, and thence by a line along the middle of St. Mary's River to the Atlantic Ocean." 18

With reference to the freedom of navigation of the Mississippi, the report of February 23 read: "That the navigation of the River Mississippi, as low down as the Southern boundary of the United States, be acknowledged and ratifled absolutely free to the subjects of the United States.

"That free commerce be allowed to the subjects of the United States with some port or ports below the southern boundary of the said states, on the River Mississippi; except for such articles as may be particularly enumerated."19

Congress, in committee of the whole, modified this to read: "That the navigation of the River Mississippi be acknowledged and ratified absolutely free to the subjects of the United States." 20

Now that Congress was beginning to assert itself in the matter, the next consideration would be an understanding with

17. Journal of the Continental Congress (1823) Vol. XIII, p. 241. (February 23, 1779).

18. ibid., Vol. XIII, p. 329 (March 17, 1779).

19. ibid., Vol. XIII, p. 242.

20. ibid., Vol. XIII, p. 330. 
Spain. A loan would be very acceptable, military ald could be used. Perhaps we might promise them Florida for the precious right of navigation. On September 10, 1779, Spain declared war on Great Britain; on September 27, Jay was commissioned to go to Madrid and instructions were issued to him.21 The first instruction stated that in case the king of Spain would accede to the Franco-American Alliance, he should not, by any agreement, be prevented from securing. the Floridas. We would, in fact guarantee the Floridas to him if he could get them from Great Britain, provided we were guaranteed the freedom of the navigation of the Mississippl to the sea. The third instruction was to obtain, if possible, a port on the 3lst parallel, on the Mississippi, as a place of deposit for American goods. 22 Jay arrived in Spain January 27, 1780. He found Florldablanca willing to talk informally but there was no indication of his intention to recommend the recognition of the United States, nor to enter into any contract which might imply such recognition. The conferences and negotiations entered into by Jay and the discouraging reception received by him do not concern us here. It is our purpose to discover the results of his efforts. When Jay reached Spain the Spanish campaign agalnst Florida was well under way. There seemed 11ttle likelihood that the 3lst parallel would be acceptable to Spain as the northern boundary of West Florida and it was even less probable that she would yield on the Mississippi question. Jay, in reporting a conversation with Floridablanca said, "He then proceeded to observe that there was but one obstacle from which he

21. Bemis, Pinckney's Treaty, p. 28.

22. Journal of the Continental Congress, Vol. XV, pp. 1118 and 1119. 
apprehended any great difficulty in forming a treaty with America, and plainly intimated that this arose from the pretensions of America to the navigation of the Mississippi. He expressed his uneasiness on this subject and entered largely into the views of Spain with respect to the boundaries... He spoke amply of the King's anxiety, resolution and firmess on this point... from which his Majesty would never recede."23 Jay presented the westerners' case when he said that," . . the Americans, almost to a man, believed that God Almighty had made that river a highway for the people of the upper country to go to the sea by; that this country was extensive and fertile; that the general, many officers and others of distinction and influence in America were deeply interested in it; that it would rapidly settle, and that the inhabitants would not readily be convinced of the justice of belng obliged either to Iive without foreign commodities, or lose the surplus of their productions, or to be obliged to transport both over rugged mountains and through an immense wilderness to and from the sea, when they daily saw a fine river flowing before their doors and offering to save them all the trouble and expense, and that without injury to Spain." Any lingering hope that Jay might have been entertalning must have been dispelled when he was told in an interview on September 23, 1780, that "... unless Spain could exclude all nations from the Gulf of Mexico, they might as well admit all; that the King would never relinquish it; that the minister regarded it as the proper object to be obtained by the war; and, that obtained he should be perfectly easy whether or no Spain procured any other cession; 
that he considered it far more important than the acquisition of Gibraltar." 24

In February, 1781, Congress altered its instructions to Jay with reference to the navigation of the river below the 31 st parallel and on a free port below this line, but he was still to insist upon the free navigation of the river above the point. He protested, in a letter to Congress, that nothing was to be gained by the lessened demands. 25 Nevertheless, he obeyed his instructions, and presented to spain certain formal propositions, of which three of the articles were:

"VI. The United States shall relinquish to his Catholic majesty, and in future forebear to use, or attempt to use, the navigation of the river Mississippi from the thirty-first degree of north latitude, that is, from the point where it leaves the United States, down to the ocean.

"VII. That his Catholic majesty shall guarantee to the United States all their respective territories.

"VIII. That the United States shall guarantee to his Catholic majesty all his dominions in America."26

Jay made this offer contingent upon Spain's acceptance -if she did not accept, we would reserve the right to the navigation. Spain made her choice; she remained firm in her position that the control of the Spanish dominions must not be menaced. The American plea had been ably and persistently advanced but the lure of empire was still strong in the Spanish mind. It was with relief that Jay received instructions to proceed to Paris to discuss a treaty with England. And with him the scene of navigation activities was shifted. Here

24. ibid., Vol. IV, pp. 145 and 146.

25. ibid., Vol. IV, p. 743 .

26. ibid., Vol. IV, p. 760 . 
again Jay was forced to battle with the combination of powers that would limit the western territory of the United States. France and Spain worked shrewdly and systematically toward the goal of securing for Spain the country on the east bank of the M1ssissipp1.27 He well knew what it would mean for the future of the United States if England's demand for the Northwest country and Spain's demand for the Southwest was met. Jay's courageous action in entering into direct negotiations with England is a well-known story. By it he avolded the danger of America's being overwhelmed in the treaty negotiations by the machinations of her associates in the war.

He did this in the face of a passive attitude rather widespread in the East. While still in Spain he had received a letter from Gouverneur Morris which in part read, ". . The difference between us appears to be absurd, in every point of view, at least on our part . . We ask a territory and a navigation. The territory we cannot occupy, the navigation we cannot enjoy. We cannot occupy this territory at present or In future, at present because we have not the men; in future because we cannot govern 1t. The most that we can expect is an emigration from the old world, whereof one hundredth, or perhaps not so much, shall be our descendants, will claim title under us to a part of the soil and then set up independence. .

"As to navigation of the Mississippi, everybody knows that the current will forever prevents ships from sailing up, however easily they may float down. Now, unless some new

27. Justin Winsor, Narrative and Critical History of the United States, Boston, 1884, Vol. VII, p. 118. 
dragon shall be found, whose teeth sown on the banks of the Ohio, will produce seamen, I know not where else they may be obtained to navigate ships abroad which can never return home.

"But if the navigation were as easy and advantageous as it is useless and Impracticable, its effect would be only the sooner to dissolve all commercial connections between us and the sooner to produce every unhappy consequence."28

Franklin had written. in quite a different tone: "Poor as we are, yet as I know we shall be rich, I would rather agree with them to buy at a great price the whole of their right on the Mississippi, than sell a drop of its waters. A neighbor might as well ask me to sell my street door."29

The negotiations with the British were greatly influenced by the events of the Revolutionary period. With the discussions narrowed down to the two parties, progress was more rapid. On the navigation question England was quite willing to recognize our demands. Article VIII of the treaty of 1783 reads: "The navigation of the River Mississippi from its source to the ocean shall remain forever free and open to all the subjects of Great Britain and the citizens of the United States."

The incomplete knowledge of the geography of the section had given rise to the impression that the Mississippi had its source in Canadian territory. With respect to our right to navigate the Mississippi to 1ts mouth, our claim seemed to lack substance. England had granted us that which she did not possess, that is, a right to the river within Spanish territory. Her claim to the navigation at its mouth had been invalidated 
by the loss of the southern territory to Spain. She was now completely removed, territorially, from the river. By what argument could America lay claim to Spanish waters from a treaty with England? A far more tenable claim was the economic necessity of securing an outlet for the western districts. Such economic rights are usually secured by one of two methods, aggressive action or mutual concessions. Which course would America take?

The general negotiations at Paris included also the British treaty with Spain by which the latter country received Florida. Between Spain and the United States, however, no understanding was reached. The boundary question and the navigation question were to be points of contention for many more years with the action transferred to yet another stage -- the United States. 
20

The Movement for Statehood in Kentucky 
As has been previously suggested the movement for statehood in Kentucky was the result of an ever increasing conviction that the problems confronting the district could never be solved as long as it remained a part of Virginia. Foremost among these problems should be placed the necessity of securing the free navigation of the Mississippi. The solution of that difficulty does not belong in this chapter but its consideration must be kept in the mind of the reader as it was ever present in the mind of the Kentuckian of that period. There were other economic considerations. The scarcity and depreciation of the currency, the first resulting to a considerable degree from the isolated condition of the region, and the second a result of Virginia impoverishment following the war, were evils that might be remedied by forming a state government unhampered by the encumbrances of an earlier day. Again it was not a question of Virginia's unwillingness to provide adequately for her western county but rather of her inability to do so.

Much of the lack of knowledge in Virginia relative to Kentucky can be attributed to the great distance intervening; to a lesser degree the lack of understanding can be attributed to the same cause. The frontiersman, accustomed to meeting his problems with prompt and decisive action, rebelled against the slow-moving machinery of a more conservative government. The westerner would solve the problem of Indian attacks by vigorous retaliation which would discourage such raids; but the Virginia government forbade these expeditions both across the Ohio and into the territory to the South. Restraint and delay were 
unappreciated elements in a land that offered so much independence and that reckoned action preferable to inaction.

The first appearance of the new state movement was, to a certain extent, prophetic of the future. The situation seems to have been marked by discontent, but discontent unaccompanied. by construetive political ideas. 30

This first separatist movement made little headway and the later movements were furthered by a different type of leaders. The division of the region into three counties and their organization into a judicial district of Virginia was the outstanding political change reswlting from the early discontent. 31

The conclusion of the treaty of peace with England was followed by a tremendous migration to Kentucky. The fact that England had promised to give up the Northwest posts was taken to mean less likelihood of Indian attacks. The migration

30. Temple Bodley, who has contributed so much to the study of Kentucky history, considers the movement as having been influenced largely by those who had left eastern homes to avoid taxation and military service and were thinking more of disestablishing one government than of establishing another. (Bodley, Kentucky, Vol. I, p. 279). He prints the following petition found in the Virginia State Library Collection (Loose) signed by fifty six of the new settlers who had come out in 1780: "We must lie under the disagreeable necessity of going down the Mississippi to the Spanish protection or becoming tenants to private gentlemen who have men employed at this juncture in this country at one hundred pounds per thousand for running around the land which is too rough a medicine ever to be digested by any set of people who have suffered as we have." This prejudice of the Pennsylvania settlers against the Virginia government and the earlier Virginia landholders is also illustrated by the letter of George Rogers Clark to his father, dated August 23, 1780," . . The partisans in those countries are again soliciting me to lead them as their Governor General, as all those from foreign states are for a new government; but my duty obliging me to suppress all such proceedings, I shall consequently lose the interest of that party." (Original letter in the Ballard Thruston collection of George Rogers Clark Papers).

31. William Waller Hening, Statutes of Virginia at Large, 13 Vols., Richmond, 1819, Vol. X, p. 315. 
was probably of a much higher order than that at the beginning of the decade. It came largely from Virginia and contained many officers and men from the Revolutionary armies. But the hope of comparative security from Indian attacks was premature. The order of Congress cutting down the army to fiftyfive at West Point and twenty-six at Pittsburgh, together with the unsettled conditions during the negotiations with the Indians, produced a situation filled with real danger. Another factor contributing to the unrest was a political one. The desire for local self-government found in the Holston settlements of western North Carolina and in the Transylvania settlement in Kentucky was equally strong in this period. 32

The particular circumstance that produced the first definite step toward statehood was a threatened invasion by the Cherokees in 1784. There seemed to be little possibility of concerted action for defense among the settlers, so Benjamin Logan, senior colonel after the retirement of General George Rogers Clark, issued a call to the heads of all military organizations to meet at Danville in November of that year to consider the situation. The assembled militiaman's convention found the immediate danger less pressing than at first reported but recogni $i_{\mathrm{z}}$ dhat the question of defense was still unsol ved and urgent. ${ }^{33}$ A second convention, to meet in December (1784)

32. For a study of "particularism" as an element in the pioneer's social concept, see Arthur P. Whitaker, The Spanish-American Frontier, Boston, 1927, p. 94.

33. A motion for immediate separation was made but was not passed. This resolution read that Kentucky "when independent ought to be taken into the Union with the United States." (Draper MSS $11 \mathrm{~J} \mathrm{37,} \mathrm{reprinted} \mathrm{in} \mathrm{Littell,} \mathrm{Political} \mathrm{Transac-}$ tions In and Concerning Kentucky). 
was decided upon and to this convention each militia company was allowed one delegate. At this convention a resolution to the effect that Kentucky should be separated from Virginia and admitted to the Confederation was passed and was ordered to be sent to the General Assembly of Virginia. A third convention, to meet in April (1785) was to bring a mandate from the people. The Journal of this Convention contains the petition sent to Virginia as well as the address sent to the people of Kentucky, setting forth the reasons for the desired separation. The petition and the address emphasized the lack of power to call out the militia, the lack of an executive power located in the district, and the impossibility of receiving benefits of government at so great a distance from the capital. The address also stressed the great difference in the economic interests of the two sections. 34

The proceedings of the third convention indicate that the chief motive of the early statehood demand, protection, had given way to the broader and more deeply rooted plea of separation for development.

Humphrey Marshall said of the petition and the address: " - - If the petition to the legislature could be accused of a deficient portraiture of grievance; and a too great reliance on matter of right, and a sense of duty -- the address to the people ran some risk of falling into the opposite extremes, and comprised under the domination of facts, a variety of topics, presented in a drapery calculated to affect their feelings -- awaken their fears -- and infuse into their minds disaffection towards the existing state of things, and

34. The Journal is printed in I1ttell, Political Transactions, Appendix, Nos. I and II, pp. 6I-66. 
the government of Virginia; from the misdeeds of which, no longer to be borne, they were taught to believe that a separation, and it alone, could relieve them." 35

The resolutions adopted at the August Convention were similar to those of the preceding convention. The concluding resolution read: "Resolved, therefore, That it is the indespensable duty of this convention, as they regard the prosperity and happiness of their constituents, themselves and posterity, to make application to the General Assembly, at the ensuing session, for an Act to separate this district from the present government forever on terms honorable to both and injurious to neither; in order that it may enjoy all the advantages, privileges and immunities of a free, sovereign and independent republic."36

The petition which accompanied the resolution likewise seemed to embody a firm conviction of the necessity for establishing an independent state. ". . Tis not ill-directed or inconsiderate zeal of a few, 1 tis not that impatience of power to which ambitious minds are prone; nor yet the baser considerations of personal interest which influence the people of Kentucky - . (they) are now impelled by expanding evils, and irremediable grievances, universally seen, felt and acknowledged, to obey the irresistible dictates of self preservation and seek for happiness by means honorable to themselves, to zou, and infurious to neither." 37

It was not to be opposition from Virginia that was to stand

35. Humphrey Marshall, History of Kentucky, Frankfort, 1824, 2 Vols., Vol. I, p. 206.

36. The Journal of the Convention (Brown, Political Beginnings of Kentucky, Appendix, No. 3).

37. Littell -- Appendix No. III, p. 69. 
in the way of Kentucky's attaining her goal. The administration problem was a difficult one for the older district and time might well make it more serious. In January, 1786, the General Assembly passed an act providing for the separation of Kentucky from the mother state and the erection of the District into a "State of the Confederation." The will of the people of Kentucky was to be ascertained through a convention to meet on the fourth Monday of September 1786. If the action of Virginia was agreeable to the Kentuckians, the assembled convention was to fix a date prior to September 1, 1787, when the authority of Virginia should cease. But in order to consummate the transfer of authority, Congress should, before June 1, 1787, agree to the entrance of the district into the Union as an independent state. 38 The continuation of authorized government was provided for in the requirement that the convention of September, 1786, should call a convention to meet prior to September 1, 1787, to draw up a constitution and to provide mules and regulations for the district until that constitution should go into effect.

But the course of separation was not so smooth. Virginia repealed her separation act and called for the election of delegates to jet another convention to be held in September, 1787 , to pass again upon the question of separation. This second act stated that "it continues to be the purpose of the general assembly that the said district shall become an independent state on the terms and conditions specified in the act aforesaid" but 1t was apparent that the delegates "have been 
hindered by unforeseen events from meeting at the time proposed and determining the question referred to them; and it is considered that no such determination can now take place within the time necessary for its receiving the assent of Congress prior to the first day of June next and as required by the act."39 In case this second act was ratified in Kentucky, then a day not later than the first day of January, 1789, should be selected upon which to make the transfer of authority. The date for the acceptance by Congress should be not later than the fourth day of July, 1788.

In the convention of September, 1787, ........ with little debate it was decided, without a dissenting vote, to be expedient for the good people of this district that it should be separated from the rest of the state upon the terms and conditions prescribed by law, ${ }^{40}$ In conformity with the directions of the General Assembly, an address was sent to Congress, petitioning for the admission of Kentucky. 41

Despite the numerous and exasperating delays, the general attitude in Kentucky seems to have been one of patient yet persistent interest. The address prepared by Innes, Muter, Sebastian and Brown has been quoted to indicate the wrath of the western country. 42 But the strongest statement in the circular is no more than a vigorous protest against possible indifference in Congress. ". We hope to see such an exertion made, upon this important occasion, as may convince

39. Hening, Vol. XII, p. 240.

40. Marshall, Kentucky, Vol. I, p. 275.

41. Littell -- Political Transactions, Appendix, No. XIII.

42. Humphrey Marshall and Thomas Marshall Green (The Spanish Conspiracy) have interpreted the address as a dangerous and inflammatory document. 
Congress that the inhabitants of the western country are united in the opposition, and consider themselves entitled to all the blessings of freemen, and those blessings provided by the revolution, and will not tamely submit to an act of oppression, which would tend to a deprivation of just rights and privileges."

The impatience of the frontiersman when he considers the injustices attendant upon delay is proverbial. Turner in a chapter upon "Pioneer Ideals," repeatedly emphasizes the pioneer's irritation at the handicaps imposed upon him by civilization which does not realize his problems. the pioneer fought his way across the continent, masterful and wasteful, preparing the way by seeking the immediate thing, rejoicing in rude strength and wilful achievement."43 In that light we can understand the tenor of the following letter used as a circular: "Preparations are now making here (if necessary) to drive the Spaniards from their settlements, at the mouth of the Mississippi. In case we are not countenanced and seconded by the United States (if we need it) our allegiance will be thrown off, and some other power applied to. Great Britain stands ready, with open arms to receive and support us. They have already offered to open their resources for our supplies. When once reunited to them 'farewell, a long farewell', to all your boasted greatness. The province of Canada, and the inhabitants of those waters of themselves, in time, will be able to conquer you. You are as ignorant of this country as Great Britain was of America. These hints, if rightly improved, may be of some service; if not, blame yourselves

43. Frederick J. Turner, The Frontier in American History, New York, 1921, p. 270. 
for the neglect." 44

Though irritation existed, the counsel of leadership was for a quiet but steady prosecution of the district's interest. It was felt that a representative living at the capital would help the cause of admission. The Virginia assembly was asked to appoint such a man and complied by selecting John Brown, who had been a judge for the Kentucky district. 45 A resolution to the effect that Kentucky should be admitted was prepared by Brown and submitted to Congress February 29, 1788. The matter was delayed in committee, a forerunner of the series of vexing delays that followed. We find that reference to the question was made on March 4, May 30, June 2, June 3, and finally upon July 2. By that time word had been officially received that the ninth state had ratified the Constitution, whereupon Congress voted to discharge the committee appointed to look into the matter and passed the following resolution: ".... as the Constitution of the United States is now ratified, Congress thinks it unadvisable to adopt any further measures for admitting the district of Kentucky into the Federal Union as an independent member thereof under the Articles of Confederation and perpetual Union, but that Congress think it expedient that the said district be made a separate state, and member of the Union, as soon after proceedings shall commence under the said constitution as circumstances shall permit. . . " 46

It was a terrific blow at Kentucky's hopes for early

44. Secret Journals of Congress, Vol. IV, p. 320, Boston, Wait, 1821.

45. Richard Collins, History of Kentucky, 2 Vols., Covington, 1882, Vol. I, p. 328.

46. Journals of Congress, Vol. IV, 830. 
admission. The dissatisfaction which had been smoldering among the more belligerent might now more easily be fanned into flame. The official proclamations likewise took on a more assertive tone. A convention called previous to the reception of the news, met at Danville on July 28. The preamble to the resolution adopted there reads as follows: "Whereas it appears to the members of this convention, that the United States in Congress assembled, have for the present declined to ratify the compact entered into between the legislature of Virginia and the people of the district respecting the erection of the district into an independent state; in consequence of which the powers vested in this convention are dissolved \& whatever order or resolution they pass cannot be considered as having any legal force or obligation, but being anxious for the safety and prosperity of ourselves and constituents, do earnestly recommend to the good people inhabiting the several counties within the said district each to elect five representatives on the times of holding their court in the month of october next to meet at Danville, on the first Monday in November following, to continue in office until the first day of January, 1790, and that they delegate to their said representatives full powers to take such measures for obtaining admission of the district as a separate and independent member of the United States of America, and the navigation of the river Mississippi, as may appear most conducive to those important purposes: and also to form a constitution of government for the district, and organize the same when they shall judge it necessary, or to do and accomplish whatever, on a consideration of the state of the district, may in their opinion promote its 
interests." 47

The wording of the resolution gives rise to conjecture. The phrase "to take measures for obtaining the navigation of the Mississippi" might be interpreted in whatever fashion the reader views the situation. It is true that negotiations with Spain could not legally be undertaken by the people of the district but certainly efforts might be made to that effect through the agencies of the United States. The importance attached to the free navigation of the river was no new thing. It had been one of the strongest elements in the agitation for statehood. With the news of the action of Congress so recently received, there is small wonder that the expression of opinion should contain vigorous mention of this most vital subject connected with their economic welfare. To "form a constitution of government" was no more than to follow the suggestion of the Virginia assembly. With such a step taken, a renewal of their negotiations with Congress might be hastened. The decision of Congress earlier in the month had no discouraging tone; there had been an expression of goodwill for their next effort. Nor would the resolution to "accomplish whatsoever . . may in their opinion promote its (Kentucky's) interests," imply more than a gesture of determination to proceed along the lines previously laid down. The action of the Convention called for the following November would seem to bear out this contention.

The record is given minutely in the Journal of the Convention. 48 Practically all of the business was carried on in

47. Kentucky Gazette, September 6, 1788.

48. Full extracts may be found in John Mason Brown, Political Beginnings in Kentucky, Louisville, 1889, pp. 257-263. 
the committee of the whole. Resolutions were offered to prepare addresses to the Virginia Assembiy and to Congress, the first relative to separation according to the suggestion of Congress -the second with reference to possible action by Congress in securing the navigation of the Mississippi. It was vigorous, but not threatening. The even temper and well-ordered plan of the leaders of Kentucky seem clearly given in the resolution offered by Brown. "That it is the wish and interest of the good people of this district to separate from the State of Virginia, and that the same be erected into an independent member of the Federal Union."

The ambitions of a frontier region had been thwarted by the caution and selfishness of a more highly developed area. But the political problem of statehood was but an indication of a more perplexing economic problem of markets and transportation. The demand for the free navigation of the Mississippi could not be shelved; it was vital to the very life of the West. And it is to that story of the West that we now turn. 
Kentuckians and Spaniards

A Study in Uncertainties 
When a people accustomed to the unrestrained life of the frontier begin to evolve into an organized community, they are likely to carry over with them into the new era their old habits of suspicion of the outsider, of quick judgments, and of impatience with "the law's delay." Such is the story of the so-called "Spanish Conspiracy." It was not an insidious intrigue, not a breaking of faith with their countrymen of the East, but simply a collection of precipitate acts, of impulsive statements, which maturity should have learned to tolerate in youth. Disgruntled individuals there were, no doubt, and selfish persons who would not have hesitated to sell their country's welfare, but they were isolated cases, such as may be found anywhere, and at any time. The Mississippi River, placid and unruffled ordinarily, but capable of sweeping before it every vestige of material development when it becomes turbulent, was the cause of this disaffection. And as the spring freshets can pile up its waters until it becomes a destroying force, so did the rising tide of indignation against the East give to certain shrewd individuals a power that threatened disaster to the region.

Jay had said that these western people belleved almost to a man that God Almighty had made this river for them to go to the sea by. And when the issue was firmly established by an order which reached Congress in June, 1784, from Madrid reading: "Until the limits of Louisiana and the two Floridas shall be settled and determined with the United States of America, his Majesty commands that you should give the states and Congress 
to understand that they are not to expose to process and confiscation the vessels which they carry on commerce on the River Mississippi inasmuch as a treaty concluded between the United States and England, on which the former ground their pretensions to the navigation of that river could not fix limits in a territory which that power did not possess, the two borders of the river being already conquered and possessed by our arms the day the treaty was made, namely the 30 th November, 1782. This order I communicate to you that you may conform yourself thereto." 49

One letter may be quoted as an expression of opinion that prevailed so widely in the West: "To give us the liberty of transporting our effects down the river to New Orleans and then be subject to the Spanish laws and impositions, is an insult upon our understanding. We know, by woeful experience, that it is in their power, when once there, to take our produce at any price they please. Large quantities of flour, tobacco, meal \&c have been taken there last summer, and mostly confiscated." 50

To present the full story of the relationship of Kentuckians and Spaniards of this period is manifestly impossible. Bearing in mind the fact that the rank and file of the Kentucky people were concerned only in solving a great economic problem, it follows, then, that the thing that we need concern ourselves most with is the activities and attitudes of their leaders. One man of great influence, however, stands apart from the rest. Of his traitorous dealings there is little

49. Secret Journals of Congress, Vol. III, p. 517. (Galvez to Rendon, June 26, 1784.

50. Secret Journals of Congress, Vol. IV (Foreign Affairs), p. 320. 
doubt, though his purpose has sometimes been open to question. This individual, Brigadier-General James Wilkinson, had come to Lexington in 1784. He was only twenty-six but with a wealth of experience, not omitting intrigues, unusual for his age. During the Revolution he had been on General Gates's staff -perhaps he had recelved valuable lessons in double-dealing there. He had participated in the Conway Cabal. The trace of distrust that Eastern leaders seem always to have had for him, he managed to dispel by an engaging manner, vigorous personality and undeniable ability. He came to Kentucky as the agent of a land company but seems early to have been attracted by the possibilities of the New Orleans trade. His plans are shrouded in the mixture of candor, duplicity and verboseness with which his writings abound.

In July, 1787, he went to New Orleans with a boat-load of Kentucky produce. The prohibition upon such commerce was well known in Kentucky; Wilkinson was certainly aware of 1 t. One theory to account for his action is that he meant to defy the order, secure thereby an interview with Miro, the governor, and win him over to his plan of a combined commercial and political arrangement. Commercially, it would mean a trade concession to Wilkinson, and to him alone. Politically, It would mean the promise of Wilkinson to secure a separation of Kentucky from Virginia and its adherence to Spain. The constantly growing fear in the Spanish minds of trouble with their northern neighbors had been augmented by two incidents, both occurring shortly before Wilkinson's trip. The first grew out of the seizure at Natchez of a boat-load of Kentucky products. North Garolina and Virginia had immediately protested 
to Congress demanding protection of their navigation rights. ${ }^{51}$ Later Colonel Thomas Green had written a letter from Lexington prophecying a descent upon New Orleans by the Americans. This letter had been intercepted by the Spaniards and presented by Gardoqui to Jay. ${ }^{52}$ That there was a real fear among the officials at New Orleans may be proved by the translated report of Intendant Navarro sent from New Orleans in 1785. He said: ". . The intensity with which they are working to form a city and establish posts, and their immediate neighborhood to our posts of the Illinois, may be harmful to us some day, unless we shelter ourselves in time by promoting a numerous population in this province to observe and even to restrain their intentions." 53

Whatever Wilkinson may have intended, he was eminently successful in storming the citadel of Spanish trade restrictions in New Orleans. His pleasing manner and eager frankness won over the governor and the intendant, Navarro. They listened to his plan and they were more than impressed when, to prove his sincerity, he offered to take an oath of allegiance to Spain and to leave in the vault of the Spaniards the proceeds of the sale of his first cargo. He submitted to the authorities a lengthy memorial which covers, in the florid manner one soon learns to assoclate with the man, the whole field of American and Spanish frontier relations. He sketched the dissatisfaction of the Kentuckians, the rapid growth of the West and their rising aggressiveness. He suggested the possibility of British initiative, with the consequent danger to Louisiana. He led

51. Diplomatic Correspondence, Vol. VI, p. 203.

52. Ibid., Vol. VI, pp. 199-262.

53. Robertson, Louisiana under Spain, France and the United States, 1785-1807, 2 Vols., Cleveland, 1911, Vol. I, p. 244: 
artfully to the question of whether it would not be better for Spain "by partial indulgence and an accommodating deportment" to win the western region than to risk the danger of their rising aggressiveness under another power. He suggested that Gardoqui be instructed to remain firm in his stand upon the navigation question but that Spain might do well to remember that "in order to conciliate and prepare the minds of the western Americans, tolerance will be good politics in certain political cases, offering it to a few parties of real influence." Honesty and truthfulness were never serious handicaps to Wilkinson, to judge from the memorial. "Be it known to your honors, that the Notables of Kentucky, the place of my residence, chafing under the inconveniences and privations they suffer through the restrictions placed on its commerce, suggested that I make this voyage in order to penetrate, if this were possible, the attitude of Spain toward this country and to discover, if this were practicable whether it would be agreeable to admit us under its protection as vassals." Among all the charges brought against certain prominent Kentucklans, there is found no evidence to verify this charge that they inspired the voyage of Wilkinson. He concluded his memorial with three suggestions: First, secrecy with respect to the plan, and his connection with it. Second, the continuance in office of Miro, as Governor of Louisiana. Third, the appointment of Navarro to be minister to the American government. 54 The oath of allegiance is likewise in the true Wilkinson

54. This memorial may be examined in the Loulslana State Historical Society Publication, Vol. IX, No, 1 and also in Bodley's Introduction to "Reprints of Littell's Political Transactions in Kentucky." These copies were obtained from the original in the Pontalba Collection. This memorial is dated August 21, 1787. 
style. Its chief value to the student lies in its application to the premise that insincerity and self-aggrandizement were compelling attributes of the man. To read it is to substantiate the conviction that Wilkinson meant to use the Spaniard's lack of Information regarding Kentucky to his own economic advantage, to gain trade concessions upon the false impression that he would be the means of winning the allegiance of Kentucky to the Spanish crown. Nothing could have been further from his purpose. Kentucky's adherence to Spain would have meant the end of his coveted trade monoply, his sole purpose in furthering the whole design. 55

There is a tendency to magnify the influence of Wilkinson in Kentucky and to attempt to connect all the impetuous statements and questionable acts in that district with his schemes. It is true that as a vigorous and self-assertive personality he was well known, but the attitude of the leaders toward him was not one of guilty connivance, but of appreciation for his supposed interest in the region. Kentucky was deceived by him as New Orleans was. To illustrate: he read before the convention of 1788 what he purported to be his memorial to the Spanish. In reality it was an expurgated form of that memorial, containing only a recital of the woes of the Kentuckians,

55. Whitaker, in his Spanish-American Frontier, accepts the idea that Wilkinson meant to detach Kentucky from the Union and to join it to Spain. But all evidence seems to point to the fact that Wilkinson meant to gain economic advantage and not political advancement, a course that could be best sensed by maintaining the situation as it was. W. R. Shepherd in his article "Wilkinson and the Spanish Conspiracy" (American Historical Review, Vol. IX, p. 490) discussed the discovery of the Spanish translations sent by Miro to Valdes, minister of war and treasurer of the Indies. They are in the Archivo-Historico-Nacionale at Madrid. The English original has never been located. 
and praying that Spain would help them by permitting New Orleans to become their market. 56 To express their gratitude the Convention voted this resolution: "Resolved that this Convention highly approve the address presented by Gen'l James Wilkinson to the Governor and Intendant of Louisiana and that the President be requested to present him the thanks of the convention for the regard which he therein manifested for the interest of the Western Country."57 Wilkinson thereupon sent a copy of the minutes, as published in the Kentucky Gazette, to Miro, in order that Miro might see for himself how well his interests were being served in Kentucky.

Though Spain had not received with approval any of the proposals presented by Jay, she was not indifferent to the importance of a commercial understanding with America. In october, 1784, Floridablanca announced that he would send a commissioner to the United States who would discuss the commercial questions, together with the Mississippi question and the problem of the boundaries. Gardoqui was the commissioner selected. Congress again chose Jay to represent America and the discussions between these two men, abandoned two years before, were resumed. Gardoqui's instructions on the boundary question were to present a claim to the territory from the Kentucky river west to the Mississippi. Concessions, however, might be made on this point. But upon the question of the navigation of the river, there should be no yielding. To Spain

56. The memorial read before the convention of November 5, 1788, may be found in Marshall, Vol. I, p. 289. The stroke was bold enough to fix attention upon the man and to make him, more than ever, a great power in political circles, but stopped short of revealing how traitorous had been his dealings in New Orleans.

57. Bodley, Vol. I, p. 445 (Reprinted from the Pontalba Papers) 
should go the exclusive right of navigation where it ran between the Spanish banks. 58

Jay was especially enjoined to assert the right of the United States "to their territorial bounds and the free navigation of the Mississippi, from the source to the ocean, as established in the treaties with Great Britain." 59 . He was not to conclude anything until he had previously communicated it to Congress and received the approval of that body. At the first meeting Jay presented the American claim to the navigation and to the boundary line of $31^{\circ}$ as set forth in the treaty with England. The privilege of West Indian trade was also requested. Gardoqui intimated that there might be discussions upon the territorial issue, but that Spain must stand firm upon navigation. The Spanish commissioner sensed, ev1dently, the difficult position in which Jay was placed. The southern delegates in Congress were concerned in keeping faith with the people of the Mississippi Valley. There was, in the ir minds, but one important problem under discussion with Spain. To the eastern delegates considerations of trade not connected with western rivers were of vital importance. Gardoqui wrote that some "men of judgment" in Congress thought that for the West to be too attractive would be a source of weakness for the whole country -- that it would be better to improve the navigation of the eastern rivers and make the nearer western regions more attractive. Some eastern interests, he found, were alarmed at the drain upon cheap labor. On the other hand, he was not at all wllling to see the Westerners aroused to the

58. Bemis, pp. 74 and 75 .

59. Resolution of July 20, 1785, Diplomatic Correspondence (Blair Edition), Vol. VI, p. 102. 
point of being a menace to Spanish settlements. 60 He proposed to placate American sentiment on the subject of the West, by special reciprocity tariff clauses between Spain and the United States, and by a treaty covering commerce and boundary, but not mentioning the navigation of the Mississippi. That would establish the principle of the river's being denied to everybody. ${ }^{61}$ By this time the interest in the possibility of statehood had assumed noticeable proportions and as shrewd an observer as Gardoqui would not fall to be aware of the increased prestige of Kentucky, should she gain her desire.

The weeks of conferences and discussions that followed led finally, in the summer of 1786 , to a compromise treaty plan which was presented to Congress. The major points were a thirty year commercial agreement, a guarantee by each of the territory of the other in America, agreement by Spain to purchase each year in America a quantity of hard wood, paying for 1t in cash specie, and finally an agreement by Spain to mediate between the United States and Great Britain for our recovery of the Northwest Posts. It was an attempt to win the American people to the support of a treaty with Spain without securing the coveted navigation. "Hard money" was scarce in the states; the condition would be remedied by the hardwood purchases. The presence of the British in the Northwest. was an irritant to American pride; Spain promised to help, even to the extent of force of arms, in their removal. To Jay the advantages of the commercial treaty were obvious,

60. Gardoqui to Conde de Galvez, Viceroy of Mexico, August 23, 1785 (Bemis, p. 84).

61. Gardoqui to Floridablanca, August 23, 1785 (Bemis, P. 84). 
as they were to the east. Yet he had been too much in touch with southern and western sentiment not to realize the value, to them, of their claim. To insure, if possible, the success of the treaty in the Congress, Jay suggested that this country forebear to use the river for thirty years. If the demands of the West could be amicably resisted for that period, time would probably solve the problem. It was a heavy price, but no treaty with Spain would likewise be a disaster. It must be remembered, however, that $\mathrm{Jay}^{\prime} \mathrm{s}$ instructions had been explicit in the matter of navigation. It was felt that the treaty, as It stood, was doomed to defeat, since the Articles of Confederation required nine votes to ratify. Might a majority of states repeal instructions with reference to a treaty, when nine were required to ratify? The discussion waxed warm; the pent up intensity of feeling over the matter burst forth. Jay was called upon to explain his plan. The eastern delegates pointed out our danger from without. We had no army and no navy; a treaty with Spain was imperative. The vote was taken. By seven states to five, Deleware being unrepresented, it was decided to repeal that part of the instructions relative to the Mississippi navigation. 62

On October 6, 1786, Jay wrote Gardoqui that "in consequence of some recent acts I find myself more in capacity than I was, to make and recelve propositions relative to certain matters In difference between our countries." 63

As a consequence of their renewed discussions there was

62. For the debates in Congress see the Journal of the Continental Congress, Vol. IV.

63. Diplomatic Correspondence, 1783-1789, Vol. VI, p. 196. 
formed the following agreement. "It is especially stipulated and concluded that his Catholic majesty and the United States are freely and in common and without any interruption from each other, to use and navigate the said river from its source down to the southern boundary of the said states, and that the United States will faithfully observe the limitations and not navigate or use the said river below, or farther down than the said boundary, in any part of its course through his majestie's countries to the mouth of the river. 64

On April 4, 1787, Congress called upon Jay for a report as to the progress being made in the Spanish negotiations. He could offer no assurance of success with reference to the Mississippi question, but was hopeful that a satisfactory adjustment might be made about the boundary. 65 The state of affairs was growing more complicated. The Annapolis Convention had given promise of a new government. Gardoqui had felt the futility of the situation and had asked for a leave of absence

64. Gardoqui to Floridablanca, Confidential \#12, September 8, 1786.

65. Censure, such as might have been expected, met these agreements. Monroe wrote Governor Patrick Henry under a New York date line of August 12, 1786: ". . Upon my arrival here in Dec ${ }^{r}$ last (having been previousiy well acquainted with Mr. Jay) in conversation with him I found he had agreed with Gardoqui to postpone the subject of the Mississipp1 \&c, in the first instance and to take up that of a commercial treaty; that in this they had gone so far as that Mr. Jay was possessed of the principles on which he wo agree to make it, upon condition on our part of the forebearance of the use of the Mississippi for 25 or 30 years. I soon found in short, that $\mathrm{Mr}$. Jay was desirous of occluding the Mississippi and of making what he termed advantageous terms in the treaty of commerce the means of affecting 1t.. From that time, and I had reason to believe he had begun even before my arrival, we have known of his intriguing with the members to carry the point." (Writings of Jas. Monroe-edited by S. M. Hamilton -- Vol. VI, pp. 144 and 145). 
while the new government was pending. From that time, aside from desultory discussions in Congress and in political centers outside, the Jay-Gardoqui treaty was reckoned as a hopeless 1ssue. It was a feeble and flickering end to a most dramatic story in our early national history. In it we find the powerful influence of a remote and undeveloped region, a prophecy of the rising importance of the West. Though the diplomatic contest in the East was not without its interesting phases, it was in the West that the action was most animated, the actors most thoroughly a part of the play, and the plot, most subtly woven.

Miro seemed to have been thoroughly won over to the scheme of Wilkinson and to have seen in it verification of his theories concerning the protection of Louisiana. He wrote to Madrid in 1788: "The delivering up of Kentucky into his master's hands, which is the main object to which Wilkinson has promised to devote himself entirely would forever constitute this province a rampart for the protection of New Spain...

"The western people would no longer have any inducement to emigrate, if they were put in possession of a free trade with us. This is the reason why this privilege should be granted only to a few individuals having influence among them, as is suggested in Wilkinson's memorial, because on their seeing the advantages bestowed on these few, they might be easily persuaded to acquire the like by becoming Spanish subjects." 66

Our interest in Wilkinson, in this paper, is primarily in

66. Despatch of January 8, 1788 -- Miro to Valdes. 
connection with his relationship to the disaffection among the Kentuckians. After 1788 circumstances tended to weaken his position, both in Kentucky and in Loulsiana. It was generally believed that the admission of the district was but a matter of a short time, upon which the major problems might wait. He could not carry on indefinitely his double deceit and so, as the new government of the United States was being put into operation we find him writing: "I discovered that the proposed new government of the United States had inspired some with apprehension, and others with hopes -- so much so that I saw that this circumstance would be a cause of some opposition and delay. I also perceived that all 1dea that Kentucky would subject itself to Spain must be abandoned for the present, and that the only feasible plan to the execution of which I had to direct my attention was that of a separation from the United States, and an alliance with Spain, on conditions which could not yet be defined with precision." 67

The whole episode was but another chapter in the adventurous career of Wilkinson, an episode that was colorful but of little real influence in the history of the West. Where correspondence and conferences with other Kentuckians have been proved, they reveal only a tendency to enlist all who would work to solve Kentucky's problems. What these other Kentuckians had in mind, no one can definitely say. Widely separated purposes have been read into their letters, their transactions, and their statements. The student can only study them for himself

67. Wilkinson to Miro, February 12, 1789 (Charles Gayarre, History of Louisiana, Spanish Domination, 4 Vols., New York, 1866, Vol. II, p. 223. 
and draw his own conclusions.

The evidence which has been advanced to prove the existerice of a Spanish Conspiracy centers around the activities of a small group of men living in Kentucky and of the delegate to Congress, John Brown. One member of this group of influential Kentuckians was Harry Innes, Attorney-General for the Kentucky District. Governor Randolph, on May 1, 1788, wrote to him asking that he "institute proper legal inquiries" concerning the infractions of peace on the part of certain Kentuckians who had taken upon themselves the privilege of punishing, by a raid, a group of Indians who had a short time before made a marauding expedition upon several Kentucky settlements. Judge Innes replied upon July 21, 1787, acknowledging the receipt of the Governor's letter upon July 6 th. He expressed himself mystified as to the measures to be taken, since he had no executive powers, and that to act in a private capacity would render him "odious." He did not understand, he said "of whom he was to enquire, or against whom he should institute persecution." He proceeded to describe frontier conditions and the danger from the Indians and concluded: "The Indians have been very troublesome on our frontiers, and still continue to molest us, from which circumstances I am decidedly of opinion that this western country will in a few years Revolt from the Union and endeavor to erect an Independent government; for under the present system we cannot exert our strength, neither does the Congress seem disposed to protect us, for we are informed that those very troops which Congress directed the several states to raise for the defense of the western country, are disbanded. I have just droppid this 
hint to your excellency for matter of reflection. If some step is not taken for our protection a little time will prove the truth of the opinion." 68 Historians convinced of the existence of a Spanish Conspiracy have made much of this letter. There are passages in the letter, it is true, that indicate the possibility of a drastic move on the part of the western country. But it would not be reasonable to assume, surely, that a man interested in furthering a revolt would announce that intention to the governor of his state several months in advance of the act. Would not a better explanation be that he wished, by magnifying the gravity of the situation, to gain additional consideration for the section? Exasperation often leads to exaggerated statements, which are not necessarily to be construed in their strictest sense.

The evidence used to prove a Spanish Conspiracy includes also the activities of John Brown, delegate from Kentucky to the Congress. His conferences with Gardoqui and the reports made to at least two prominent Kentuckians are the basis for this charge.

68. Virginia Calendar of State Papers, Vol. IV, p. 322. Reprinted also in Bodley's Introduction to Iittell, No. $X$ in Appendix but differing from the letter received by Randolph in that the words "Revolt from the Union" are not included. The letter used by Littell was from a copy retained by Innes, presumably the first draft, when he dispatched his warning to Randolph. In 1806 an editorial in the "Western World" charged four men in Kentucky, Wilkinson, Innes, Sebastian and Brown, with having been implicated in a separatist plot. Iittell's book is written in defense of these men, especially of Innes and Brown. Whether Innes altered the copy of the letter submitted to Iittell or whether he had attached little importance to the difference in the two wordings, the student must decide for himself. The most damaging of the two manuscripts is used here, since it seems the most authentic, but its admission as evidence does not prove a "Spanish Conspiracy." 
The evidence rests largely on letters to two men. To one, Samuel McDowe1l, president of each of the eight conventions, he wrote: "In a conversation I had with Mr. Gardoqui, the Spanish Minister, relative to the navigation of the Mississippi, he stated that if the people of Kentucky would erect themselves into an independent state, and appoint a proper person to negotiate with him, he had authority for that purpose and would enter into an arrangement with them for the exportation of the1r produce to New Orleans on terms of mutual advantage."69 The letter to Muter is likewise of interest, "In private conferences which I had with Mr. Gardoqui, the Spanish minister at this place, I have been assured by him in the most explicit terms, that if Kentucky will declare her independence and empower some proper person to negotiate with him, that he has authority and will engage to open the navigation of the Mississippl for the exportation of their produce on terms of mutual advantage; but that privilege can never be extended to them while part of the United States, by reason of commercial treaties existing between that Court and other powers of Europe. As there is no reason to doubt the sincerity of this declaration, I have thought proper to communicate it to a few confidential friends in the district, with his permission, not doubting but they will make prudent use of the information which is in part confirmed by despatches yesterday received by Congress from Mr. Carmichael, our minister at that court, the contents of which I am not at

69. The above letter was quoted from memory by McDowell in a letter published in the Palladium (Frankfort) of August 7 , 1806. It is reprinted in Brown, Political Beginnings, Appendix, No. V. 
liberty to disclose."70 Brown continued with the statement that the movement for statehood had gone too far to be abandoned, and that the need for admission into the Union was too great to await the long delays. He attributed the failure to achieve statehood at that time as due to "the jealousy of the growing importance of the western country, and an unwillingness to add a vote to the southern interest." It would appear that Brown was assiduously following the instructions that he keep in touch with the developments in the capital. It is signiflcant that he sent to McDowell the more cautious of these two letters. In all the flurry connected with the Spanish question no hint of suspicion was ever directed toward McDowell. To Muter, Brown evidently felt that he could be more confidential. To McDowell he said: Separate from Virginia and Spain will treat with you in a manner advantageous to both upon the navigation question. To Muter he said: Spain holds that it will be necessary to separate from the United States to secure the things we desire.

A study of other letters may be a help in arriving at a decision. One of the most incriminating is from Gardoqui to Floridablanca. He wrote: ".. This determination (i.e. to delay granting separation to Kentucky) was very distasteful to those who promoted the separation of the district, and particularly to $\mathrm{Mr}$. John Brown, a landed proprietor and resident in that district, who was interested in that matter, among others, as member in Congress. . Foreseeing some of

70. Brown to Muter -- July 10, 1788. Marshall, the historian, had this letter from Muter. See Marshall, Vol. I, p. 307 . 
these occurrences, I took occasion during the past year to cultivate the acquaintance of the aforesald Brown and to introduce such topics as I thought would produce good results. "Our friendship gradually increased and my sentiments naturally made an impression on him, inasmuch as they touched upon those obstacles imposed by our treaties with other nations which forbade us according any extension in favor of his section of the country while pertaining to the United States, artfully insinuating that only themselves could remove this difficulty; inasmuch as if separated they would afford excuse for regarding them as an interior district without maritime designs, and perhaps we could devise some plan of adjusting the markets so much needed in some of our possessions. I carefully observed his appearance as I told him this, and it seemed to me that I could discern the satisfaction that it gave. I repeated (several days later) the same and other observations. He seemed quite satisfied and obliged to me, and admitted, in confidence, that he had, by a messenger who had left some days before, communicated to his constituents the decisions of Congress concerning the separation. . He told me, in conclusion, that this month the convention would meet and that he expected it would resolve upon the erection of an independent state; that he expected to leave this place the lst of August, and that he would arrive in time to inform and aid what he had discussed with me, for he deems it a very fit and important subject for consideration, and for the present he thanked me for himself and in the name of all the country, which would be under lasting obligations to me..."71 Another letter involving Brown was

71. Gardoqui to Floridablanca, No. 279, July 25, 1788. 
written by Miro to Valdes." ". Oliver Pollock, a citizen of Philadelphia, who arrived here three days ago in a vessel from Martinique, has disclosed to me that Brown, a member of Congress, who is a man of property in Kentucky, told him in confidence that, in the debates of that body on the question of the independence of that territory, he saw clearly that the intention of his colleagues was, that Kentucky should remain under the jurisdiction of Congress, like the county of Illinois, and that a governor should be appointed by them for that province as for the other; but that, as this was opposed to the welfare of the inhabitants of Kentucky, he was determined to return home, and on his arrival, to call for a general assembly, of his fellow citizens, in order to proceed immediately to declare themselves independent, and to propose to Spain the opening of a commercial intercourse with reciprocal advantages; and that, to accomplish this object, he would send to Pollock the necessary documents, to be laid before me and to be forwarded to your excellency..." 172

of the Gardoqui letter to Floridablanca it is possible to make too much. Assuming that Brown felt a greater obligation to work for the interest of the section than to attempt to maintain its connection with the United States, there 1s nothing to warrant the assertion that he was working for an alliance with Spain. The letter is largely a statement of Gardoqui's opinion as to the impression he had made upon Brown. As a glimpse into the character and mode of operation of the Spaniard it is valuable. But as proof of a Spanish Conspiracy

72. Miro to Valdes, Nov, 3, 1788. (Gayarre, Louisiana, Vol. I, p. 222.) 
it is sadly unconvincing. In this letter, as in the Miro letter above, the Spanish officials fail to appreciate the first consideration in the minds of the Kentuckians -- that of statehood. Organized as a state, they might successfully cope with the problem of navigation and market. But to desire a union with Spain as an end within itself was opposed to the very essence of the frontier nature. It was to that grandiose Spanish concept that Wilkinson appealed, and the response must have been, to him, most gratifying. But in Kentucky were men who were carrying on the fight for their section's interests in the face of combined indifference and jealousy on the part of the East and daring to say and do those things which the occasions demanded. With the exception of Wilkinson's case there is no evidence that any of these men expected to profit politically or financially from the separatist movement. Indeed their action might be deemed as springing from an ideal of patriotism rather than from selfish motives. The frontiersman has ever been inclined to put his local community, rather than the nation, in the foreground of his interests.

Admitting, then, the doubtful nature, in the light of national interests, of Brown's activities, there is nothing to justify the contention that he was a party to or an organizer of a conspiracy. Aside from two letters, written in confidence with a request for information, and several letters by Spanish officials who never understood the situation, there is no basis for charges against him. The following statement by an unfiendly historian regarding the Gardoqui letter seems totally unwarranted: "Eve, as she looked with fascinated eye upon the hateful head and deadly coils of the arch enemy of 
man, did not more easily nor more eagerly succumb."73 The idea

so firmly implanted in the minds of the general reader of

Kentucky's history, that there was a Spanish Conspiracy, is

largely the result of such assertions; the evidence however, is lacking. 74

Isaac Shelby, the first governor of Kentucky, in a deposition

73. Green, Spanish Conspiracy, p. 160.

74. The high place which Brown held and continued to hold in the esteem of men of prominence, is illustrated in a letter from Madison to Mann Butier, Kentucky Historian:

Dear SirmMontpelier, oct. 11, 1834.

"I have received your letter of the 2lst ult. in which you wish to obtain my recollections of what passed between $\mathrm{Mr}$. Brown and me in 1788 on the overtures of Gardoqui

that if the people of Kentucky will erect themselves into an independen't state, and appoint a proper person to negotlate with him, he had authority for that purpose and would enter into an arrangement with them for the exportation of their produce to New Orleans.'

"My recollection, with which reference to my manuscript papers accords, leaves no doubt but that the overture was communicated to me by Mr. Brown. Nor can I doubt that, as stated by him, I expressed the opinion and apprehension that a knowledge of it in Kentucky, might in the excitement there, be mischievously employed. This view of the subject resulted from the natural and wellknown impatience of the people on the waters of the Mississippi for a market for the products of their exuberant soil; from a distrust of the Federal policy, produced by the project for surrendering the use of the river for a term of years; and from a coincidence of the overture in point of time, with the plan on foot for consolidating the Union by arming it with new powers, an object, to embarrass and defeat which, the dismembering aims of Spain would not fail to make the most tempting sacrifices, and to spare no intrigues.

"I owe it to Mr. Brown, with whom I was in intimate friendship, when we were associated in public life, to observe that I have always regarded him, whilst steadily attentive to the interests of his constituents, as duly impressed with the importance of the Union, and anxious for its prosperity. I pray you to accept with my respects, my cordial salutations.

"Mann Butler, Esq. "Signed James Madison"

(Collins, History of Kentucky, Vol. I, p. 328) Upon the admission of Kentucky, Brown was made one of the first United States senators. He had previously served as United States senator from Virginia. 
in the suit of Innes against Marshall said: "I was a member of nearly all the early conventions held at Danville but can not certify the particular years. I have a recollection of most of the important subjects that were discussed. In no convention of which I was a member did I ever hear a motion or proposition made by. any member to separate Kentucky from the United States and form a connection with Spain. Such a proposition, in my opinion, and the author of it, would have been treated with scorn and contempt in every convention of which I was a member." 75

Certainly not everybody who had discussions with Gardoqui could be accused of conspiracy in the western question. Governor Randolph was evidently in communication with Gardoqui through Madison. In a letter to Randolph, Madison sald: ". . The information which you wished to go to Mr. Gardoqui has boen communicated. The real impression made by it cannot be seen through the political veil. If he views the state of western affairs in the true light, his representations to Spain must convince her that she has no option but between concession and hostilities. It is to be lamented that so many circums tances have concurred to enlist her pride on the side of the latter alternative. "76

In this period of tremendous change and adjustment in America, the price of leadership was frequently the severest of condemnation. Hamilton and Jefferson knew it; Jay returned to the country following the signing of the treaty with

75. Deposition in Mercer County Court, August, 1813. Printed in Brown, p. 166.

76. Madison to Randolph -- April 2, 1787 (Madison Papers, Vol. II, p. 629). 
England to be met with a storm of abuse. But it was the peculiar misfortune of the Kentuckians that the slander has, in many quarters, followed them to the present time. But whatever the cost to them, their section received the reward of their efforts. The formation of a new state and the opening of the Mississipp1, issues treated with indifference in the East, were soon to remove those experiments so fatal to nationalism. 
Statehood and Navigation Concluded 
In conclusion, Kentucky, faithful to America but seeking her own interests also, felt that they could best be obtained through statehood in the Union, not outside. Her leaders kept an eye open to other possibilities but they never were brought to the point of despairing of seeing their aims accomplished by legal means. The new constitution, combining national authority with local self-government held out hopes of Kentucky's achieving both her aims -- liberty in the economic and in the political sense. These hopes soon were fulfilled.

Kentucky's two problems, developing through the early frontier period together and together threatening the destiny of the section, were brought to satisfactory conclusion but three years apart. After 1789, the story of statehood lacks the dramatic nature of the earlier period. Persistence with patience rather than impatience, marks its pages. The Kentucky Convention of 1789 asked Virginia again to pave the way for statehood. The Virginia legislature complied; Congress passed an act, February 4, 1791, providing for admission on June 1, 1792. The struggle was over. Kentucky, so long accustomed to settling her own affairs quietly passed into her new position.

The companion story, more complicated, cannot be adequateIy treated here. Its national and international character made necessary the delays which the frontiersmen had come to know so well. The consummation of the treaty with Spain, attempted so many years before by Jay, had several contributing factors. The Nooka Crisis with England had produced considerable 
uneasiness in Spain. ${ }^{77}$ The possibility of trouble with the two English speaking nations at once was doubly alarming.

Carmichael, the American charge des affaires, had been instructed to hammer ceaselessly upon the idea of a treaty, and to add strength to our position, France was persuaded to use her influence in our behalf.

In 1794, came our treaty with England into which the overwrought minds of the Spanish diplomats read a secret clause against Spain. Briefly and succinctly has Bemis summed up the situation when he framed as the accompanying title to his recent book, "Pinckney's Treaty" the phrase "America's Advantages from Europe's Distress." 78

On January 11, 1792, President Washington transmitted to the Senate the text of a report from the Secretary of State as to the advisability of reopening the negotiations with Spain. 79 In an accompanying note, the President nominated William Short, charge des affaires at Paris, to work with Carmichael. Later at the rather childish request of Spain a man of "more dignity and rank" was appointed to head the delegation. Thomas Pinckney of the famous South Carolina family was selected and to him is ascribed the honor of the treaty of 1795 .

The settlement of the long negotiation over the Mississippi navigation is found in Article IV: "It is likewise agreed that the western boundary of the United States which

77. For a discussion of this incident, see Bemis, Jay's Treaty, New York, 1923, pp. 52-78.

78. For a thorough and readable account of these later years of the negotiations, see Bemis, Pinckney's Treaty.

79. American State Papers, Vol. I, No. 55. 
separates them from the Spanish colony of Louisiana, is the middle of the channel or bed of the River Mississippi from the northern boundary of the said states to the completion of the thirty-first degree of latitude North of the Equator; and his Catholic Majesty has likewise agreed that the navigation of the said River in its whole breadth from its source to the ocean, shall be free only to his subjects and the citizens of the United States, unless he should extend this privilege to the subjects of other powers by special convention." 80

Spain's contention to her sole right to the navigation of the lower Mississippi was thus consistently maintained. The article agreed to by Spain bears more the nature of a grant than a recognition of right. The recognition that Spain tacitly made was, that her period of domination in America was over; henceforth she must stand aside for the rising power here. Kentucky with a spirit now idealistic, now selfish, but always aggressive, was a symbol for the irresistible march of the new nation upon the West.

$$
--* 0 *-
$$

80. For the text of this treaty in both English and Spanish, see Appendix to Bemis, Pinckney's Treaty. 
Bibliography 
General References

Bemis, Samuel Flagg -- Jay's Treaty, New York, 1923.

Bodley, Temple -- History of Kentucky, 4 Vols., Louisville, 1928.

Collins, Richard -- History of Kentucky, 2 Vols., Covington, 1882.

Roosevelt, Theodore -- Winning of the West, 6 Vols.

Turner, Frederick J. -- The Frontier in American History, New York, 1921.

Winsor, Justin -- Narrative and Critical History of the United States, Boston, 1884.

Winsor, Justin -- The Westward Movement, Boston, 1897.

Special References

American Historical Review.

Bemis, Samuel Flagg -- Pinckney's Treaty, Baltimore, 1926.

Filson, John -- Discovery, Settlement and Present State of Kentucke, 1793.

French, Benjamin F. -- Historical Documents of Louisiana, New York, 1846.

Gayarre, Charles -- History of Louisiana, 4 Vols., New York, 1866.

Green, Thomas Marshall -- The Spanish Conspiracy, Cincinnati, 1891.

Imlay, Gilbert -- A Topographical Description of the Western Territory of North America, 1793.

Kentucky Gazette.

Iittell - - Political Transactions In and Concerning Kentucky (Reprinted by Temple Bodley, with Introduction).

Marsha11, Humphrey -- History of Kentucky, 2 Vols., Frankfort, 1824.

Political Science Quarterly.

Robertson, James Alexander -- Louisiana under Spanish, French and United States Domination, 4 Vols., Cleveland, 1911. 
Special References (Continued)

Sparks, Jared -- The Life of Gouveneur Morris, Boston, 1832. Whitaker, Arthur P. -- The Spanish-American Frontier, Boston, 1927.

Documents

American State Papers.

Diplomatic Correspondence of the Revolution (Blair Edition), Wa shington, 1837.

Diplomatic Correspondence of the Revolution (Wharton Edition). Hening, William Waller -- Statutes of Virginia at Large, 13 Vols., Richmond, 1819.

Journal of the Continental Congress, 1823.

MacDonald, William -- Documentary Source Book of American His tory, New York, 1916.

Madison Papers (edited by Henry Gilpin), Washington, 1842. Secret Journals of Congress, Boston, Wait, 1821. 